\title{
Three-dimensional geologic modeling and groundwater flow modeling of the Töllinperä aquifer in the Hitura nickel mine area, Finland - providing the framework for restoration and protection of the aquifer
}

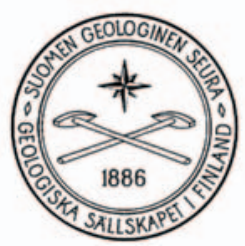

\author{
Aki Artimo ${ }^{1)^{*}}$, Veli-Pekka Salonen ${ }^{2)}$, Silja Pietilä̈ ${ }^{\mathrm{I}}$ And Sami Saraper $\ddot{A}^{\mathrm{I}}$ \\ 1) Department of Quaternary Geology, University of Turku, FIN-20014 Turku, Finland \\ 2) Department of Geology and Palaeontology, University of Helsinki, FIN-00014 Helsin- \\ $k i$, Finland
}

\begin{abstract}
Elevated concentrations of sulphate, chloride, and nickel were discovered in water samples taken from the Töllinperä aquifer in western Finland. The area is located adjacent to the tailings area of the Hitura nickel mine. Earlier studies revealed that the groundwater contamination resulted from tailings-derived mine waters leaking from a tailings impoundment area. The tailings area directly overlies the Weichselian esker system, part of which is the Töllinperä classified groundwater area.

The observed groundwater and surface water contamination resulted in a need to characterize the subsurface geology in the whole area of the contaminated esker aquifer. The primary sedimentary units were introduced into a three-dimensional (3-D) geologic model of the aquifer made with EarthVision ${ }^{\odot}$ geologic modeling software. The information obtained from the 3-D geological model was then introduced into a numerical groundwater flow model made with MODFLOW code, which was calibrated with MODFLOWP code.

The results of this study were used to guide the sealing of the tailings impoundment in order to prevent the further contamination of the Töllinperä aquifer. The groundwater flow model was used to interpret and simulate the flow system, and to provide a plan to safely continue water supply to local inhabitants from the unpolluted parts of the aquifer.
\end{abstract}

Key words: environmental geology, aquifers, ground water, eskers, three-dimensional models, ground-water flow, numerical models, pollution, acid mine drainage, protection, Töllinperä, Hitura, Finland

\section{Introduction}

The proportion of all the drinking water derived from groundwater in Finland has increased significantly during the last decades. Being such an important resource, groundwater has been protected under strict environmental law, which unambiguously prohibits pollution of these reserves (Finnish Water Act 264/ 1961 and Finn-

\footnotetext{
* Corresponding author: aki.artimo@turunseudunvesi.fi

Present address: Turku Region Water Ltd.

Maariankatu 1, FIN-20100 Turku, Finland
}

ish Environmental Protection Act 86/2000). Nevertheless, groundwater pollution has occurred, especially where the knowledge of subsurface geology has been lacking. Therefore, the availability of geological information regarding the delineation and geographic extent of aquifers, their stratigraphic position, and their hydraulic properties becomes essential in protecting the groundwater reserves. The importance of hydrogeological and hydrostratigraphical information is more acute in the event of pollu- 


\section{$\because \circ$ Interlobate complex Area of passive ice End-moraine Youngest direction of ice movement}

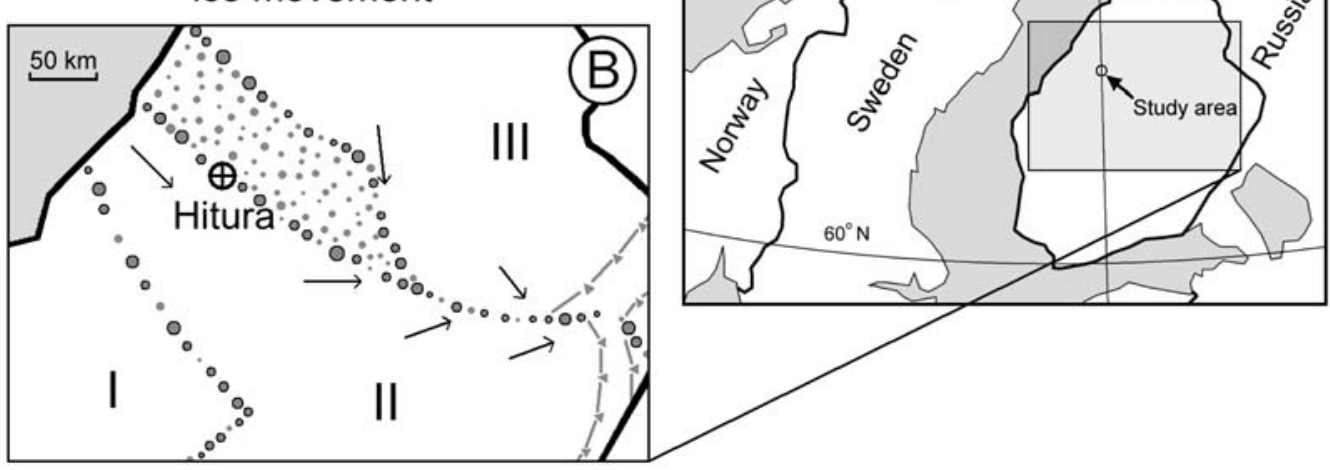

Fig. I. a) Location of the study area. b) The detailed figure shows the locations of the major ice lobes (I-III) of the Scandinavian Ice Sheet and the areas of passive ice during deglaciation in Central Finland. Modified from Punkari (1979).

tion of structurally complex esker aquifers, typical for Finland (see e.g. Artimo, 2002; Nystén, 1994).

The Töllinperä aquifer is located in western Finland close to the Hitura nickel mine (Fig. 1a). Part of the aquifer has been defined as a classified groundwater area by the Finnish environmental authorities (Britschgi \& Gustafsson, 1996), because it provides potable water to a local community.

The Hitura nickel mine and concentrating plant have been operating over 30 years, with an average annual production of the nickel concentrate about 3000 tons. The main ore minerals of the low-grade $\mathrm{Ni}$-Cu ore bodies are pentlandite, chalcopyrite, and pyrrhotite (Isohanni et al., 1985). Milling of this magmatic pentlandite ore takes place adjacent to the mine. The resulting tailings, along with the waste waters, are pumped as a slurry into a tailings impoundment located 250 meters south of the mill. The southern parts of the tailings disposal area overlie a Weichselian esker aquifer, which subsequently has become contaminated due to the mining activity.
Even though the tailings have been surrounded by an embankment and a seepage ditch, they have adversely impacted groundwater quality resulting in elevated concentrations of sulphate, nickel, and chloride in the northwestern side of the tailings disposal area for about 20 years (e.g. Juhola, 1983; Wihuri \& Ikäheimo, 1985; Heikkinen et al., 2002). Early discovery of contamination resulted in the installation of pumping wells to protect the aquifer. However, the pumping was not adequate to prevent further contamination of the area, as shown by KorkkaNiemi et al. (1999).

The aquifer on the northwestern side of the tailings area is not part of the Töllinperä classified groundwater area although it belongs to the same esker system as exists in other parts of the study area. The aquifer extends from southeast to northwest through the southern and middle part of the tailings area (Fig. 2). Even though groundwater contamination has been reported outside the classified groundwater area, on the northwestern side of the tailings area for about 20 years, it was an observed increase in sulphate 


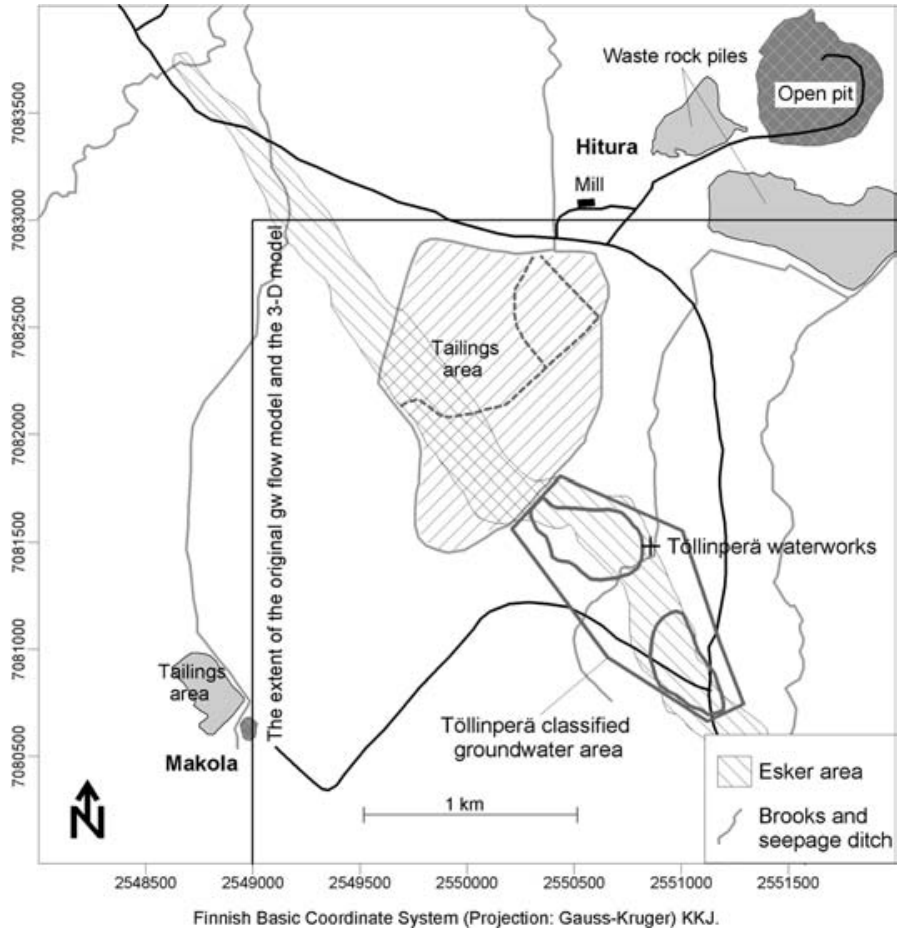

Fig. 2. Locations of the tailings area, Weichselian esker system, and the Töllinperä classified groundwater area. The outer limit of the classified groundwater area $\left(0.6 \mathrm{~km}^{2}\right)$ represents the area in which land and water use restrictions are imposed by the Finnish Water Act and the Finnish Environmental Protection Act, whereas the inner limit represents the interpreted groundwater recharge area. concentrations in the local waterworks in the Töllinperä classified groundwater area southeast from the tailings impoundment that forced the environmental authorities to require the Hitura mine to restore the aquifer. The water intake from the Töllinperä waterworks was discontinued in 1998 (Salonen et al., 2001; Heikkinen et al., 2002).

The geological complexity of the esker aquifer and unpredictable routes of the mine waste leachates were found to be unreliably represented using a single layer groundwater flow model. For this reason a 3-D geological model and a numerical groundwater flow model were constructed to interpret the flow system of the Hitura tailings embankment area and to obtain information to support the restoration and protection of the aquifer. This paper describes the procedure of constructing the mentioned models and the application of the models for restoration of mine water impacted aquifer.

\section{Study area}

The Hitura nickel mine is located in the RaaheLadoga Zone, which contains considerable number of the Finnish sulphide ore deposits. The bedrock in the area consists mainly of Precambrian migmatites, black schists, and ultramafic rocks (Isohanni et al., 1985). The mining takes place in the Kalajokilaakso Valley, which is covered by clays deposited in the Ancylus Lake and the Litorina Sea. The open pit mine cuts through a Saalian esker system, which underlies glacial and postglacial clays (Ignatius \& Leskelä, 1970; Kokkola, 1975). This older esker system is not geographically connected with the Weichselian esker system, which is the focus of this investigation. The Weichselian esker system is an interlobate feature, that formed between an active southwestern icelobe and a passive northeastern icelobe (Fig. 1b). The two interacting ice lobes have resulted in different till topographies 
on different sides of the esker and in till covered esker deposits (Punkari, 1980).

The Töllinperä classified groundwater area (Fig. 2) is bordered by the tailings impoundment on its northwestern side. The esker system directly underlies the tailings area and extends from Töllinperä to the northwestern side of the tailings disposal area (Fig. 2). The elevation of the top of the tailings is over 100 metres above sea level in contrast to the esker system, which is about 85-100 metres above sea level.

The main aquifer unit in the study area is a buried esker, which is not topographically visible. This aquifer is mostly unconfined. However, the Töllinperä waterworks is located in the confined part of the aquifer (Fig. 2). The flow connection from the main esker unit into the waterworks takes place through the distal sands of the esker, which are covered by glacial (Weichselian) and postglacial clays (Kukkonen \& Korpijaakko, 1983a,b; Salonen et al., 2001).

The study area defined for this investigation was considerably larger than the Töllinperä clas- sified groundwater area so that 3-D geological mapping and groundwater flow modeling boundaries would not end abruptly, but rather extend beyond the area of focus in a more natural fashion. The study area for the 3-D geological model covers $9 \mathrm{~km}^{2}$, including the entire tailings disposal area and also some parts of the aquifer northwest of the tailings area. The coverage of the groundwater flow model later expanded the study area by 1 kilometer to north and 1 kilometer to west, resulting in an additional $7 \mathrm{~km}^{2}$.

\section{Observations and field data}

Soil maps were used to create an overview of the study area (Kukkonen \& Korpijaakko, 1983a; 1983b). However, to fulfill the needs of this study, additional field investigations were undertaken. Open pit excavations were made in 44 locations (Fig. 3) and sedimentological features were observed from these excavation pits (Pietilä 2000). Hydraulic heads were measured from

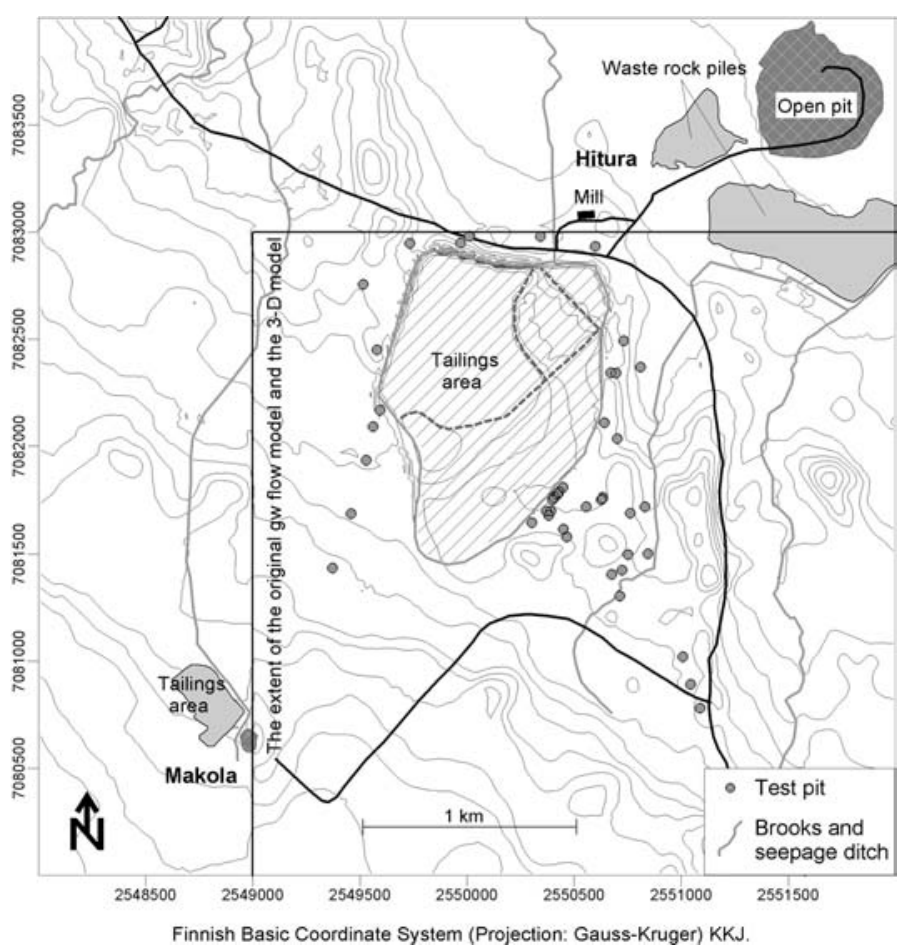

Fig. 3. Locations of the test pits and the elevation of the land surface obtained from the digital elevation model (DEM). 

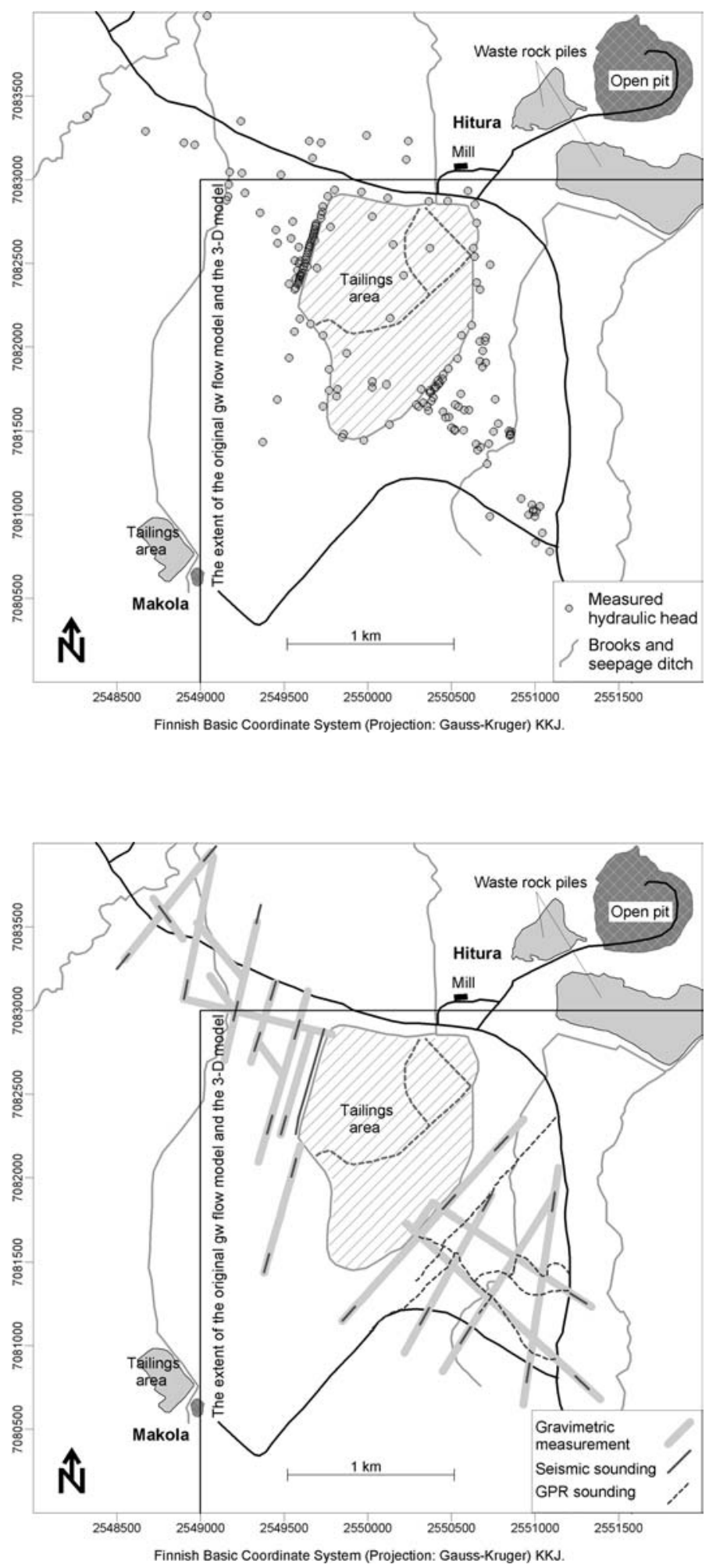

Fig. 4. Measuring locations for determining hydraulic head.
Fig. 5. Locations of geophysical studies (gravimetrics, seismic soundings, GPR soundings). 
176 locations including groundwater monitoring wells, household wells, and surface water bodies (Fig. 4). Bedrock topography was interpreted from gravimetric measurements calibrated with seismic soundings (GTK 26.11.1999, GTK 23.10.2001) (Fig. 5) and drillings. Some GPR soundings reached the bedrock surface in the areas where the bedrock was close to earth surface (Fig. 5). The outreach of the GPR soundings in the study area was 8 meters at most due to unfavorable measuring conditions.

Test drilling for obtaining representative samples for describing and for building monitoring wells at the study area has been conducted. Many of the drilling sites are located in the embankment of the tailings and inside the tailings area. Most of the older drillings were done with percussion technology and did not always reach the bedrock surface. Twelve new rotary drillings were made in connection with an aquifer pumptest study (Artimo \& Pousar, 1999, Unpublished report, University of Turku), and eight rotary drillings were made in the tailings area (Heikkinen et al., 2002). Groundwater monitoring wells were installed into these 20 new drill holes (the hydraulic head observations from these locations are included on Figure 4).

The main sedimentological units of the area were identified from the open pit excavations. These observations were accompanied with detailed surficial mapping of geologic deposits (Pietilä, 2000). GPR profiles were used to delineate the lateral continuity of observed sedimentological units. In addition, hydraulic conductivity measurements were measured on 11 samples (Pietilä, 2000).

Although recent investigations did not provide a proven confirmation that the esker system underlies the tailings, the continuity of the esker system under the tailings area was identified in a report with maps showing the location of gravel pits in the southern part of the tailings area before the opening of the nickel mine (Kokkola, 1973). This report included information about the grain-size changes of excavated materials in the area later covered with tailings.
Model input values for groundwater flow modeling were obtained from the research data accompanied with some values obtained from the literature. The observed grain-size distribution and soil type, for example, were used to control the magnitude of the input values.

\section{Methods}

\section{I.Three-dimensional geological model}

The data for 3-D geological modeling was prepared mostly with Surfer ${ }^{(B)}$ software. Three-dimensional geological modeling was conducted at the Illinois State Geological Survey with EarthVision $^{\oplus}$ geologic modeling software. The input data for the EarthVision ${ }^{\odot}$ software were in ascii-xyz format and in a form of matrices (made with Surfer ${ }^{(\otimes)}$ software) for bedrock surface and land surface (obtained from the DEM). There were a total number of 5 geological units identified in the model. The modeled units include a relatively impermeable bedrock unit, a till unit, an interlobate esker unit, a silt and clay unit, and a littoral sand unit. The 3-D geological model consists of 20 meter x 20 meter cells covering the initial $3 \mathrm{~km} \times 3 \mathrm{~km}\left(9 \mathrm{~km}^{2}\right)$ study area. The vertical resolution of the $3-\mathrm{D}$ model cells is 5 meters.

The units included in the 3-D model were determined on the basis of their sedimentological features as observed from test pits (Fig. 3), while the limits of these observed units were determined on the basis of all the research data mentioned earlier. The division of the units in the 3-D model represents the basic division of the earth materials used in the traditional 2-D geological mapping, with the exception that the silts and clays were combined into one unit.

\subsection{Groundwater flow model}

The information obtained from the 3-D geological model was used in the groundwater flow model with some modifications. The groundwater flow model was used to create an overview of the flow connections and hydrogeolog- 
ical features of the study area. Modeling was made with MODFLOW code (McDonald and Harbaugh, 1988) and the model was calibrated with MODFLOWP code (Hill, 1992). MODPATH was used for particle tracking. The field data were considered inadequate for contaminant transport modeling, because initial concentrations for detected contaminants were not obtainable, and the timing of the pollution was not clear due to lack of appropriate monitoring data.

The groundwater flow model has two layers based on the 5 geological units included into the 3-D geological model. The first version of the groundwater flow model covered an area of $9 \mathrm{~km}^{2}$, but was later extended to cover 16 $\mathrm{km}^{2}$. The extended version had 200 rows and 200 columns consisting of 20 meter x 20 meter cells.

Because of the vertical variation of the aquifer properties, it was required that the aquifer would be represented in two layers. The other units were described with horizontal changes in hydraulic conductivities and other model input values. Two model layers were required to represent the confined flow under the clay covered area from the main esker unit to the Töllinperä waterworks. Seasonal variation of the hydraulic head was not significant, which resulted in a steady state flow simulation.

Aquifer parameter values were obtained from the field observations (Salonen et al., 2001) and from the literature (e.g. Freeze \& Cherry, 1979; Zheng \& Bennett, 1995). These included, for example, horizontal and vertical hydraulic conductivities, effective porosity values, aquifer thicknesses, and recharge ratios for different parts of the aquifer.

Aquifer boundary conditions were determined on the basis of the observation data. The hydraulic head was defined to coincide with the relatively impermeable bedrock surface in the northern and northeastern parts of the study area. Dewatering of the mine had caused the drawdown of the water table, which was represented as an inactive area in the northeastern part of the flow model. Specified head boundaries with the elevation converging to the bedrock elevation adjacent to the inactive area were used to represent the observed situation in the flow model. Due to the stability of the front of the drawdown area, this procedure was considered appropriate. It was also possible to define the southwestern till covered part of the model area as a specified head boundary. This region is far enough from the main aquifer unit so that none of the simulated stresses had any impact in this area.

\subsection{Calibration of the flow model}

Hill et al. (1998) present various options to define spatially distributed quantities in groundwater flow model calibration. In this study, the zonation method of automatic calibration (MODFLOWP) was chosen to calibrate the hydraulic conductivities of the modeled area. The zonation was based on the predefined geologic units obtained from the 3-D geological model. Some units were differentiated from each other in a single model layer by horizontal changes in hydraulic conductivities, areal recharge, and effective porosities. The zonation method accompanied with the simplification of the model structure reduced the number of parameter values to be estimated, while still preserving the fundamental geological and hydrogeological information in the flow model.

\section{Results}

The elevation of the land surface, as displayed in the 3-D geological model, is presented in Figure 6. The units of the 3-D geological model are presented in Figure 7.

Effective porosity of the earth materials in the study area varies from 0.08 to 0.25 . Recharge in the esker areas in Finland has been estimated to be $60 \%$ of the annual rainfall (Niini \& Niini, 1995; Korkka-Niemi \& Salonen, 1996). In the Töllinperä aquifer, the recharge values were estimated to vary from $16 \mathrm{~mm} /$ year to $253 \mathrm{~mm} /$ 


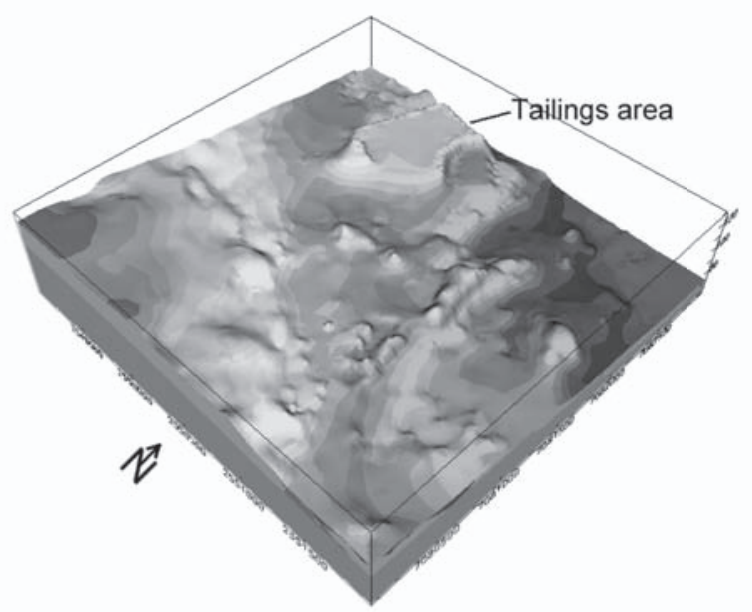

Fig. 6. The 3-D geological model showing the elevation of the land surface.

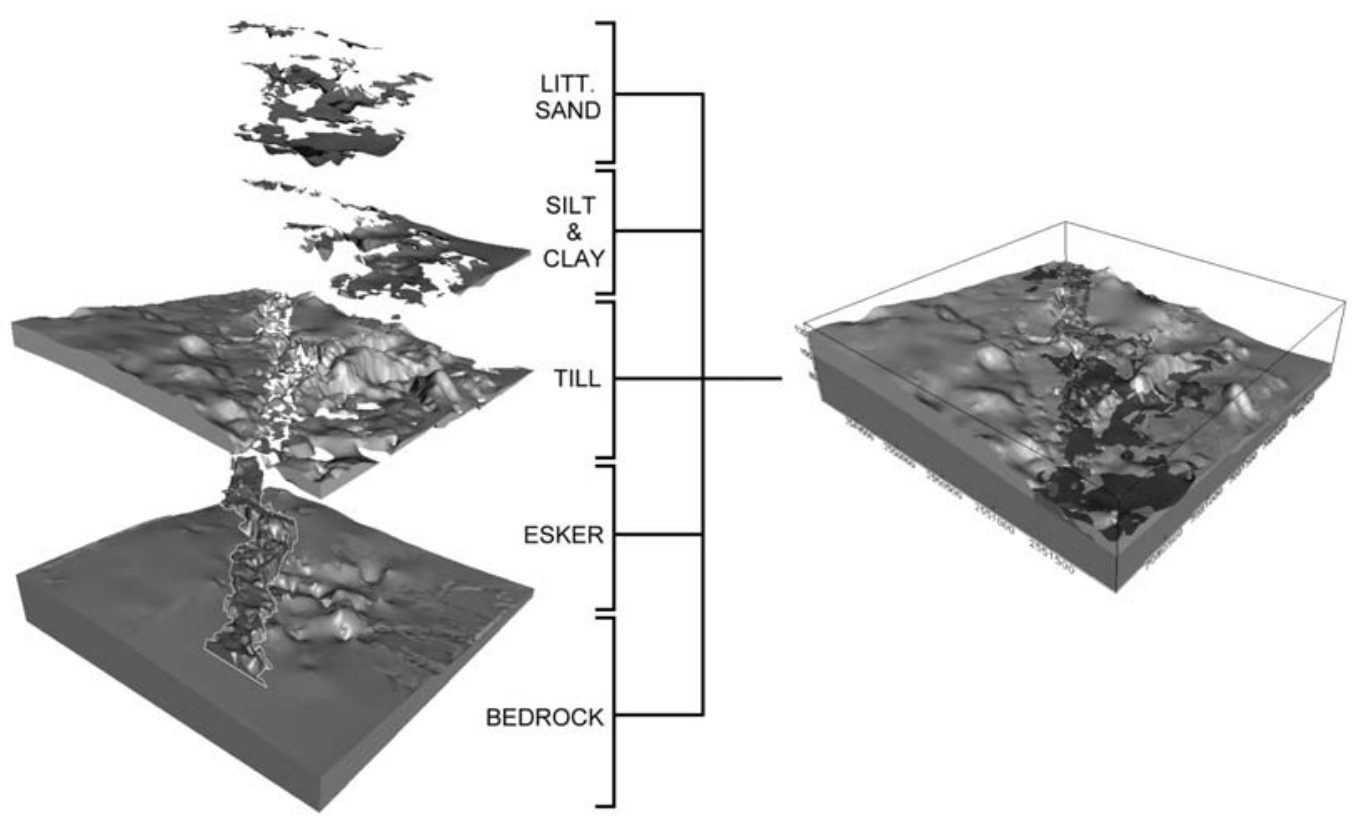

Fig. 7. The units of the 3-D geological model covering the initial study area of $3 \mathrm{~km} \times 3 \mathrm{~km}$ (tailings unit removed).

year. However, in most of the areas, recharge is estimated at more than $100 \mathrm{~mm} /$ year. Discharge occurs mostly in the agricultural areas, which are underdrained. Specific yield and specific storage values were not needed in the steady state simulation. Calculated head is presented in Figure 8 . The sum of squared weighted residuals for 110 observations was 35.96, with the average weighted residual being $-0.11 \mathrm{~m}$. Comparison of measured and simulated head in measuring locations is presented in Figure 9. Calibrated aquifer transmissivity $(\mathrm{T})$ values are presented in Figure 10. 


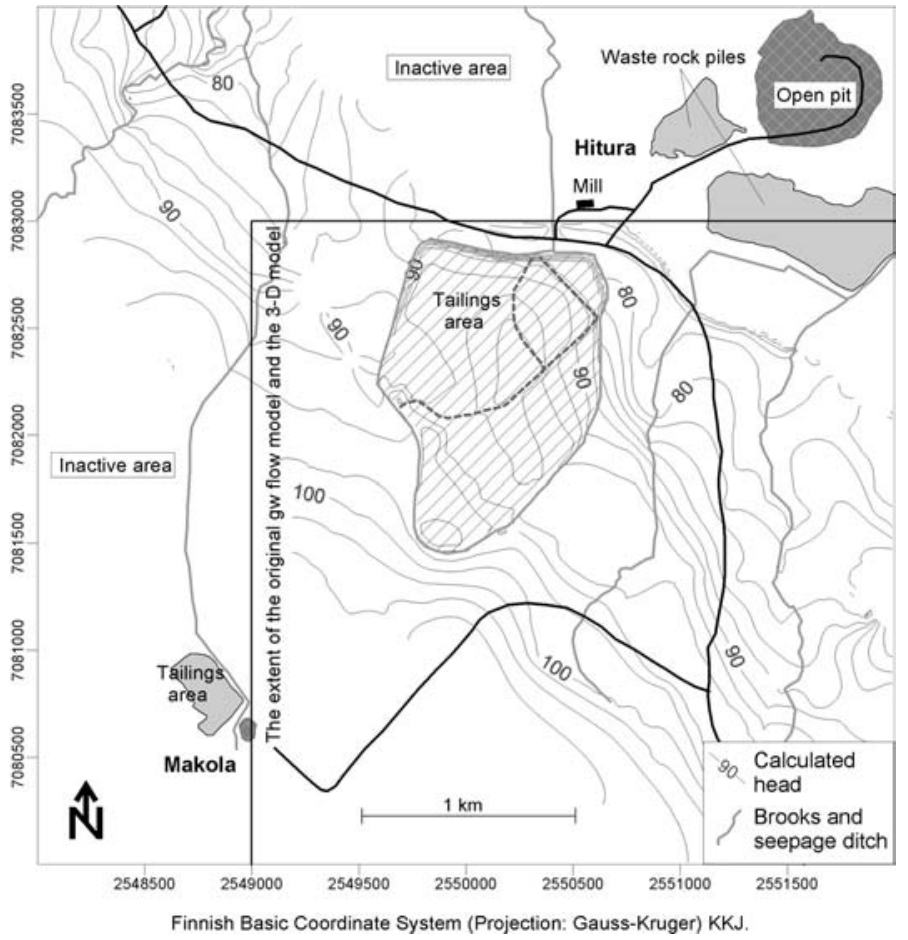

Fig. 8. Model calculated hydraulic head (metres above sea level).
As a result of the geological mapping and characterization conducted in this study, the flow connection and leakage of the mine derived waste waters from the tailings disposal area into the Töllinperä aquifer (classified groundwater area) on the southeastern side of the tailings impoundment were located. The results were then verified with groundwater flow model simulations. According to our observations, the leakage occurred when the water level in the tailings area was higher and the flow connection under the embankment was operational. This resulted in opening, reconstructing, and sealing of the tailings embankment adjacent to the esker aquifer (Salonen et al., 2001). The seepage ditch was also deepened to further prevent the flow connection between the tailings and the Töllinperä aquifer.

The flow simulation after the sealing of the embankment is presented in Figure 11, which shows that in normal conditions (when the water level in the tailings area is low) the ground- water flow direction in the Töllinperä classified groundwater area is towards the northwest. However, the direction can change very easily due to the exceptionally flat gradient of the hy-

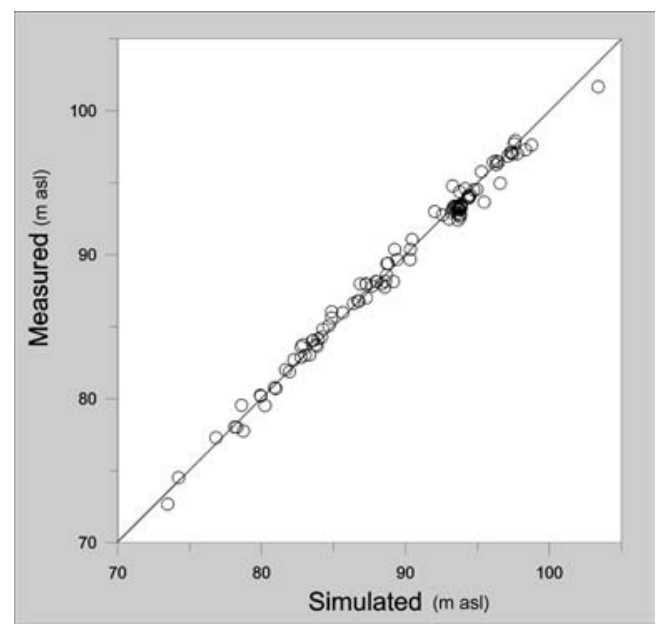

Fig. 9. Comparison of measured and simulated hydraulic heads in observation locations (head values metres above sea level). 

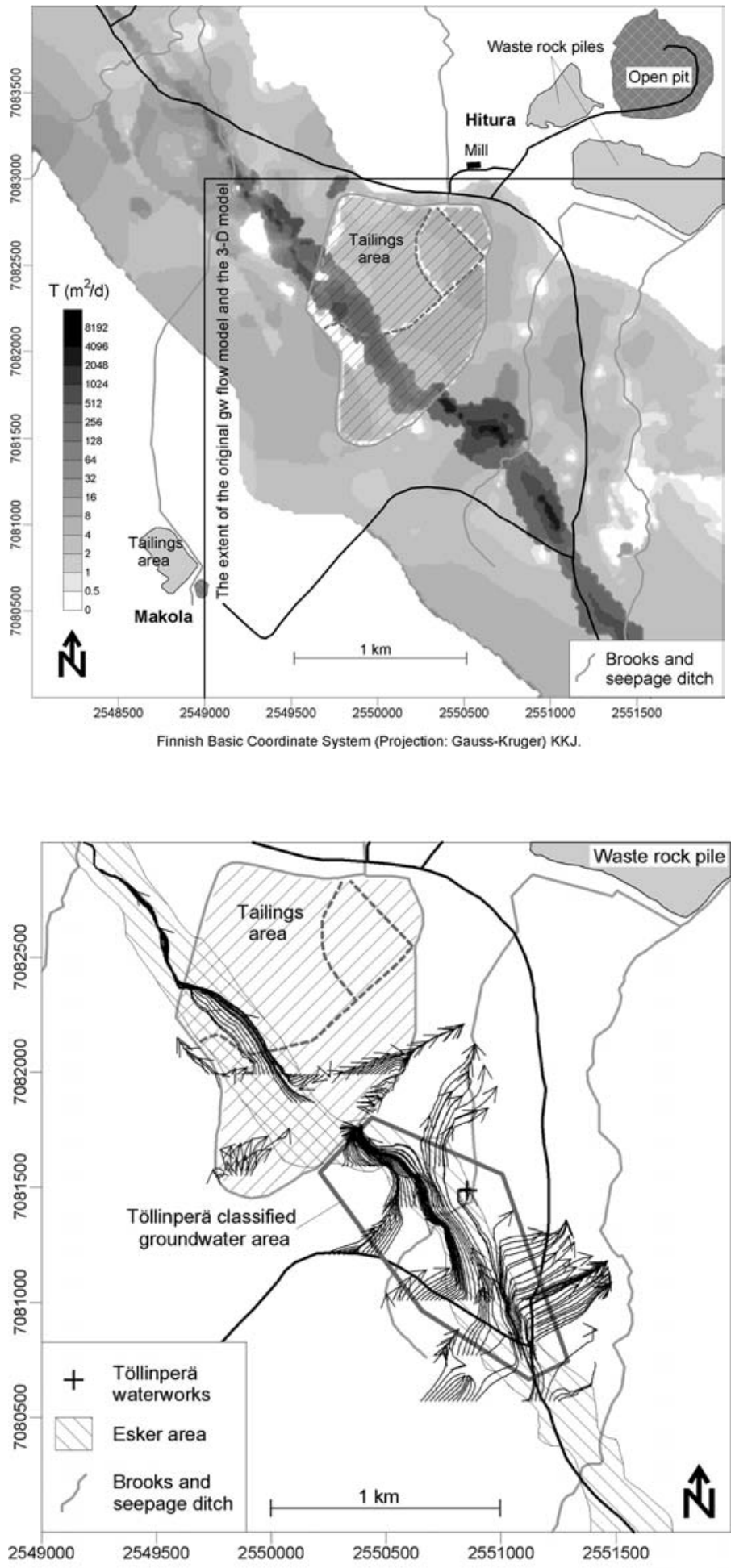

Finnish Basic Coordinate System (Projection: Gauss-Kruger) KKJ
Fig. 10. Calibrated aquifer transmissivity values in the main aquifer layer $\left(\mathrm{m}^{2} / \mathrm{d}\right)$.
Fig. II. Groundwater flow paths from selected cell locations of the groundwater flow model. The flow pattern represents the situation after the sealing of the tailings embankment. The flow lines portray the groundwater flow in 10 years. Presented area is $3 \mathrm{~km} \times 3 \mathrm{~km}$ (initial flow model area). 
draulic head in the esker aquifer $(0 \mathrm{~cm}$ to $20 \mathrm{~cm}$ / 500 metres from the tailings area to southeast). Figure 11 also shows the location of leakage of mine derived waters in the northwestern part of the tailings area, which has not been sealed yet.

The upper surface of the tailings area was represented by the elevation of the land surface (DEM) included in the 3-D geological model. The upper surfaces of the other geological units were intended to coincide with the DEM outside the tailings area. This, however, was not the case due to minor undulation of the surfaces caused by the interpolation processes. This caused the tailings unit to appear in thin patches outside the tailings area covering the other soil units. The problem was solved in latter 3-D mapping projects as shown by Artimo et al. (2003).

\section{Discussion}

The groundwater flow modeling done for this study provided the information needed for planning the relocation of the water intake operations in the Töllinperä classified groundwater area. The overview of the flow conditions within the study area was obtained with needed accuracy. However, small-scale variation of the hydraulic properties in the tailings material introduced complications in the tailings area in the flow model. The flow barriers caused by the inner and outer tailings embankments along with the steep hydraulic gradients on the edges of the tailings impoundment resulted in instabilities in earlier stages of the flow modeling. To correct for the instabilities, it was necessary to simplify the flow model in the area of the tailings impoundment. Nevertheless, it was possible to simulate the interaction of the tailings area with sufficient accuracy based on the comparison of the model simulations and recent observations.

Relocation of the new water intake plant in the Töllinperä aquifer should be planned in such a manner that the pumping operation will not extract the contaminated portion of water to contaminate unpolluted parts of the aquifer.
This requires controlling of the pumping rates at least in the early phases of the water extraction. The flow model simulations have indicated that the water intake rates of the planned new Töllinperä waterworks could be increased substantially in comparison with the water intake rates of the old waterworks without a risk of deterioration of the water quality.

It should be noted that initial efforts to further protect potable water supplies have been accomplished by the sealing of the tailings impoundment adjacent to the Töllinperä aquifer. However, the groundwater quality must be tested to ensure that the natural attenuation process will proceed as expected.

The most recent actions of preventing the groundwater from being contaminated from the tailings have focused on the northwestern side of the tailings impoundment. This caused the need to extend the original flow model area further north and west. The flow connections from the tailings area into the surrounding aquifer have been studied using new observation pits and installing new pumping wells to limit the flow of waste waters into the aquifer. Recent observations support the assumptions that the tailings embankment was constructed from heterogenous material, which resulted in variability in permeation properties of the embankment. This enables the waste waters to enter into certain surrounding areas through the embankment and under the seepage ditch. The groundwater flow model will be updated according to these observations.

\section{Conclusions}

Accurate 3-D geological characterization and hydrogeological assessment of the subsurface environment provide the keys to better understand the nature of the groundwater reserves. The 3-D geologic model that was developed for this study is an internally consistent solids model that represents the geometry, hydrostratigraphy, and sedimentology of aquifer and aquiclude units, and their interrelationships. This 
study emphasizes that the design and layout of groundwater flow models need to be based on the observed geological structures and architecture of the studied area, which are readily obtainable from the 3-D geological models. The 3$\mathrm{D}$ modeling efforts, however, are rarely carried out in aquifer mapping projects, even though the benefits for characterization, visualization, and flow modeling purposes are obvious. The reason for this usually is because of limited timescales and financial resources.

This paper focused on the 3-D characterization of the flow conditions of the study area, and the presented results and simulations were restricted to fulfill this goal. However, the results of the models provided the needed information to safely continue extracting water from the unpolluted parts of the Töllinperä classified groundwater area. Moreover, the groundwater flow model will be used to further simulate the effects of the closure procedures of the mine including the covering of the tailings area with till material to prevent rainfall from penetrating the tailings.

\section{Acknowledgements}

The authors would like to thank Kari Pulkkinen from the Hitura mine and all the people involved with the field work during these years. We also wish to thank the people from the Illinois State Geological Survey, especially Dick Berg, Curt Abert and Bill Shilts, for the opportunity to construct the 3-D geological model in Champaign, Illinois, USA. The reviewers of the manuscript Ardith Hansel, Olli Breilin and Petri Peltonen are thanked for their constructive comments. The study was supported by the Outokumpu Ltd. Hitura mine, the Illinois State Geological Survey, the University of Turku, and the Graduate School in Environmental Geology.

Editorial handling: Timo Tarvainen

\section{References}

Artimo, A., 2002. Application of flow and transport models to the polluted Honkala aquifer, Säkylä, Finland. Boreal Environment Research 7, 161-172.

Artimo, A., Mäkinen, J., Berg, R.C., Abert, C.C. \& Salonen, V.-P., 2003. Three-dimensional geologic modeling and visualization of the Virttaankangas aquifer, southwestern Finland. Hydrogeology Journal 11, 378-386.
Britschgi, R. \& Gustafsson, J., 1996. Suomen luokitellut pohjavesialueet. Abstract: The classified groundwater areas in Finland. Suomen ympäristö 55, 387 p.

Freeze, R.A. \& Cherry, J.A., 1979. Groundwater. Prentice-Hall, Inc. Englewood Cliffs, N.J., 604 p.

Heikkinen, P.M., Korkka-Niemi, K., Lahti, M. \& Salonen, V.-P., 2002. Groundwater and surface water contamination in the area of the Hitura nickel mine, western Finland. Environmental Geology 42, 313-329.

Hill, M.C., 1992. A computer program (MODFLOWP) for estimating parameters of a transient, three-dimensional, ground-water flow model using nonlinear regression. U.S. Geological Survey Open-File Report 91-484, $358 \mathrm{p}$.

Hill, M.C., Cooley, R.L. \& Pollock, D.W., 1988. A Controlled Experiment in Ground Water Flow Model Calibration. Ground Water 36, 520-535.

Ignatius, H. \& Leskelä, S., 1970. Interstadiaalinen tai interglasiaalinen kerrostuma Nivalan Hiturassa. Summary: An Interstadial or Interglacial Deposit in Hitura, Nivala, west-central Finland. Geologi 22, 61-64.

Isohanni, M., Ohenoja, V. \& Papunen, H., 1985. Geology and nickel-copper ores of the Nivala area. In: $\mathrm{Pa}-$ punen, H., Gorbunov, G.I. (eds.) Nickel-copper deposits of the Baltic Shield and Scandinavian Caledonides. Geological Survey of Finland, Bulletin 333, 211-228.

Juhola, M., 1983. Outokumpu Oy, Hituran kaivos. Havaintoputkien asentaminen jätealueen länsipuolelle välillä PL 820-1100 ja vesinäytteiden ottaminen. Pohjavahvistus Oy, Juhola/mp SV 601. Helsinki 6.1.1983. Unpublished report, $4 \mathrm{p}$.

Kokkola M., 1973. Hituran alueen sorainventointi. Raportti 010/2344/Mkla/73. Outokumpu Oy, Malminetsintä. $11+4 \mathrm{p}$.

Kokkola, M., 1975. Stratigraphy of till at Hitura openpit, Nivala, western Finland, and its bearing on geochemical prospecting. In: Jones, M.J. (ed.) Prospecting in Areas of Glaciated Terrain, Institution of Mining and Metallurgy, 149-154.

Korkka-Niemi, K., Mustikkamäki, U.-P., Pulkkinen, K. \& Salonen, V.-P., 1999. Contaminative tailings drainage impact on groundwater at Hitura, Finland. In: Fendekova, M. \& Fendek, M. (eds.) Proceedings of XXIX Congress of International Association of Hydrogeologists. Hydrogeology and land use management. Bratislava, Slovak Republic, 6.-10.9.1999, 803-808.

Kukkonen, E. \& Korpijaakko, M., 1983a. Karvoskylä. Map of Quaternary Deposits 1:20 000. Map sheet: 2344 05. Geological Survey of Finland.

Kukkonen, E. \& Korpijaakko, M., 1983b. Pidisjärvi. Map of Quaternary Deposits 1:20 000. Map sheet 234402. Geological Survey of Finland.

McDonald, M.G. \& Harbaugh, A.W., 1988. A modular three-dimensional finite-difference ground-water flow model. U.S. Geological Survey Techniques of WaterResources Investigations, book 6, chap. A1, 586 p.

Niini, H. \& Niini, S., 1995. Vesigeologia : Hydrogeologia. Teknillinen korkeakoulu, Espoo, 176 p.

Nystén, T., 1994. Mathematical modelling of groundwater pollution in a small heterogeneous aquifer at Kärkölä, southern Finland. Yhteenveto: Kärkölän likaantuneen pohjavesialueen matemaattinen mallinnus. Publications of the Water and Environment Research Institute 15, $75 \mathrm{p}$.

Pietilä, S., 2000. Hituran alueen maaperä. M.Sc. thesis, University of Turku, $72+19 \mathrm{p}$. 
Punkari, M., 1979. Skandinavian jäätikön deglasiaatiovaiheen kielekevirrat Etelä-Suomessa. Summary: The ice lobes of the Scandinavian ice sheet during the deglaciation in South Finland. Geologi 31, 22-28.

Punkari, M., 1980. The ice lobes of the Scandinavian ice sheet during the deglaciation in Finland. Boreas 9, 307-310.

Salonen, V.-P., Artimo, A., Heikkinen, P.M., Korkka-Niemi, K., Pietilä, S., Nuutilainen, O. \& Pulkkinen, K. 2001. Hituran kaivoksen rikastushiekka-alueen jätevesivaikutuksen torjunta Töllinperän pohjavesialueella. In: Salonen, V.-P., Korkka-Niemi, K. (toim.) Kirjoituksia pohjavedestä. Turun yliopisto, Geologian laitos, 251-263.
Wihuri, H. \& Ikäheimo, J., 1985. Outokumpu Oy, Hituran kaivos. Jätealueelta suotautuvien likavesien ympäristöhaitta ja torjunnan periaateratkaisu. Maa ja Vesi Oy. F60834. 29.3.1985. Unpublished report, 21 p.

Zheng, C. \& Bennett, G.D., 1995. Applied Contaminan Transport Modeling, Theory and Practice. Van Nostrand Reinhold, USA, 440 p. 
